\title{
Retrato do Irã ${ }^{1}$
}

Betty Mindlin

M RELATO de dez dias de viagem, quando da lavra de uma escritora com pleno domínio de sua arte, erudita e ficcionista, pode transformar-se no quadro de um país e de seu clima político, cultural e social. É o caso de Passeport à l'iranienne [Passaporte iraniano] (classificado como romance na folha de rosto), uma descrição da passagem da autora Nahal Tajadod por Teerã, onde nasceu e viveu até os 17 anos. Acompanhada da filhinha pequena, Kiara, cujo pai é o cineasta Jean-Claude Carrière, ela vai visitar a terra natal, rever parentes e amigos e tentar renovar seu passaporte iraniano ela é também cidadã francesa. Percebe-se que vai com frequência, tem até mesmo um apartamento na cidade.

Desde as primeiras páginas do livro dividido em capítulos correspondentes aos dias da semana, um sábado até a terça-feira da segunda semana -, o quotidiano e os afazeres aparentemente sem importância ou só pessoais vão compondo o conjunto das características de um país, de relações humanas muito particulares, de uma sociedade e cultura. Surge, como pano de fundo, um esboço do regime autoritário e fundamentalista, e das fortes reações em direção à liberdade que ela vai observando em quem encontra.

Tudo gira em torno da tarefa insana de documentação, com a burocracia e os estratagemas necessários para fugir à espera interminável. Ao acaso, ela recorre a fotógrafos vizinhos, que se oferecem para resolver todos os seus problemas, desde estofar cadeiras e instalar antena parabólica, ilegal no Irã, até apresentá-la a um médico legista capaz de tornar mais ágil, segundo prometem, a obtenção do passaporte. Vamos nos inteirando, nas páginas bem-humoradas de Nahal, do "jeitinho" iraniano, combinado a estratagemas de toda sorte para burlar regras e valorizar supostos serviços úteis. O médico legista tem influência junto a militares por dissecar cadáveres e talvez fazer tráfico de órgãos - mas após muitas peripécias, sua intervenção mostra ser inútil. Nahal perde horas e dias no trânsito iraniano, pior que o de São Paulo ou da cidade do México, em providências kafkianas sem resultado.

Essas aventuras permitem-lhe, porém, contar-nos como é a vida dos iranianos. Para tirar a fotografia do passaporte, entrar nas repartições públicas, ou mesmo circular nas ruas, as mulheres são obrigadas a esconder qualquer mecha de cabelo, saltos altos, unhas pintadas, batons, trajes ocidentais ou considerados impudicos. Disfarçam-se sob vestes largas ou chador. Funcionárias examinam quem entra nos prédios do governo, vasculham roupas e bolsas, buscando o que é proibido. As mulheres não podem dar a mão ou olhar os homens, nem sequer amigos ou parentes com quem tinham a maior intimidade. Patrulhas de costumes prendem os desobedientes, jovens em grande maioria, multam-nos, e, se não pagam, submetem-nos a castigos corporais. Bebidas alcoólicas, vinho, nem pensar. Todos se tratam de você, jamais de senhor ou senhora. Depois da Revolução de 1979, as mulheres só são chamadas de mãe, o que irrita Nahal sobremaneira. No entanto, todos infringem as regras. As funcionárias oferecem comida a uma Nahal desfalecendo de fome, admiram (e ganham) 
o batom encontrado na bolsa, reclamam da rigidez que "eles" lhes impõem. Os taxistas a tratam por senhora com o respeito de tempos antigos, seus visitantes fotógrafos ou outros the dão a mão. As mulheres passam férias em Dubai, paraíso sonhado das iranianas burguesas, exibindo biquínis nas praias e usando decotes. Nos restaurantes, veem-se casais de namorados camuflando carícias, cafés de lésbicas, roupas colantes e mocinhas magras usando perfumes e bolsas ocidentais. Há uma solidariedade tácita e generalizada, inventiva, contra a mão de ferro das normas opressivas. Contrabandistas obtêm vinho e outras bebidas, assim como caviar a preços baixos. Bebe-se muito nas embaixadas, fabrica-se um (péssimo) vinho doméstico servido em garrafas de Coca-Cola. Antes, diz Nahal, os iranianos bebiam na rua e rezavam em casa; agora exibem a religião nas ruas e bebem escondidos em suas salas. A revista $\mathrm{Vo}^{-}$ gue e outras de modas são prestigiadas, e a empregada de Nahal morre de ciúme quando ela oferece alguns exemplares aos fotógrafos cuja irmã é costureira. Tudo é possível, debaixo do pano. Sentimos a alegria de mudanças inevitáveis, que virão do anseio de liberdade da população como um todo. E do desejo de consumo (nem sempre um belo modelo).

(Antes de 1979, estrangeiros visitantes conseguiam manter o comportamento e roupas que eram seus, como eu mesma pude observar. Diante das condições atuais, é extraordinário pensar que viajei por todo o Irã usando uma minissaia e uma camiseta decotada - hoje seria presa na primeira esquina, se estivesse na Teerã do livro de Nahal. Era 1970, época do xá Pahlevi. Muito jovem, magrinha, ingênua, enfrentava o calor insuportável do mês de julho, sem me dar conta de ofen- der ou entrar em choque com os costumes do povo que desejava conhecer. Exibi minhas pernas em Teerã, Ispahan, Shiraz, Persépolis, sem jamais ser submetida a nenhuma inconveniência ou insulto. Uma vez, ao sair sozinha pelas ruas de Teerã, uma pequena multidão de meninos de dez a doze anos cercou-me, deitou-se no chão, e olhou para cima, para o que devia lhes parecer o céu, encoberto apenas pela pouca metragem de pano azul marinho. Eu achei graça e nos tratamos com gentileza recíproca. Com as mulheres, vestidas de negro, ainda com o rosto descoberto, eu me sentia inteiramente à vontade, $\mathrm{e}$ "conversávamos" como velhas cúmplices e amigas, com uma palavra mágica, Pelé, identificando meu país e origem, abre-te sésamo da geografia desconhecida.)

O refinamento dessa cultura milenar, muito anterior ao islamismo e aos árabes - que também criaram um denso universo artístico e literário -, é aparente nos pequenos eventos diários. Há o hábito do "tarof", de recusar gentilezas ou oferecimento de comida e presentes, espécie de pechincha às avessas, que retarda em ritual a aceitação de favores, como o pagamento de um jantar, um táxi, ou mesmo uma transação comercial. As iguarias elaboradas, sucos e doces coloridos, mesmo em lugares populares, dão água na boca. As fórmulas de polidez são poéticas, como "que vossa alma saboreie a doçura dessa sobremesa...", e assim por diante. A hospitalidade e o calor humano dissolvem a impessoalidade de uma grande metrópole, lembrando um Brasil arcaico.

E sobretudo a apreciação da poesia e da literatura clássica, oral e escrita, em toda parte e a toda hora. Matando a fome em um boteco, depois de um dia de peregrinação infrutífera pela burocracia, Nahal e um amigo, tradutor de Balzac 


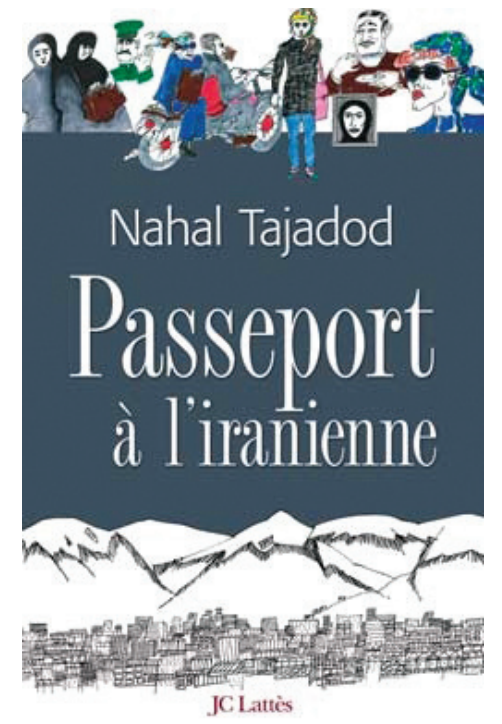

TAJADOD, Tajadod. Passeport à l'iranienne. Paris: JC Lattès, 2007.

para o farsi, ouvem um contador recitar o começo do Shahnameh ou O livro dos Reis, epopeia mítica da Pérsia antiga, de Ferdowsi, poeta do século X, exaltando os feitos de uma heroína guerreira. Todos conhecem e sabem de cor.

Quando Nahal já achava que demoraria meses para conseguir o passaporte, antevendo o marido ansioso ir sem ela ao Festival de Cannes, e temendo não chegar a tempo para sua própria conferência na França sobre a relação entre budismo e sufismo, uma jornada mágica é a reviravolta. Ela vai com a tia e a filhinha visitar Fayaz, o mais famoso marionetista do Irã, para convidá-lo, em nome de Jean-Claude, para o festival de teatro de Montpellier. Nessa tarde feérica, em que os personagens dos clássicos são encenados pelos bonecos, o marionetista oferece a influência de um amigo presente, oficial ligado às autoridades, que no dia seguinte, com manobras sutis e clandestinas, consegue em minutos o passaporte per- dido. Trata-se de um admirador da arte francesa e de Jean-Claude; apoiou muitos grandes artistas famosos em viagem ao Irã.

Ao encanto do espetáculo de marionetes, soma-se uma coincidência mágica: a casa que visitaram é vizinha àquela onde a tia que a acompanha e a avó de Nahal moraram há quarenta anos. A tia conserva uma chave da casa que nunca mais vira, e abre agora o cadeado do portão...

Ao cenário do Irã, Nahal acrescenta, em pinceladas esparsas, muito sobre sua vida. É filha de escritores estudiosos ilustrados em muitos campos. Seu pai traduziu para o persa o Fibrist de Al-Nadim, um célebre catálogo árabe do século X. A mãe, de origem curda, pintava, cantava, escrevia. Tinha terras na região de Mâzandarân, onde seus ancestrais instalaram-se no século XVI, a convite dos reis safavidas. Nahal evoca um belo amor da adolescência, aos 14 anos, uma verdadeira poesia. Também em seu romance sobre a vida de Rumi, Nahal faz uma sedutora referência à sua vida pessoal, contando que tentou durante dez anos ter filhos, e o nascimento de Kiara atrasou a publicação do livro, mas foi, como num verso de seu personagem, "sangue transformado em leite". Sua biografia romanceada de Rumi, escrita na primeira pessoa, na voz masculina, é de uma extrema delicadeza ao tratar as formas amorosas diversas e a experiência mística, e muita habilidade ao recriar o clima histórico e o personagem um livro cuja tradução para o português é indispensável (Tajadod, 2004).

Nahal tem uma relação indireta com o Brasil - seu marido Jean-Claude é o roteirista de Brincando nos campos do senhor, filme de Hector Babenco, e conhece bem a Amazônia e a cultura brasileira. A artista Federica Matta, que morou no 
Brasil e fala português, filha do grande surrealista chileno Roberto Matta, é amiga e colaboradora do casal, e publicou com Nahal, entre outras coisas, um livro encantador, Sur les pas de Rûmi, para o qual fez belíssimas ilustrações (Matta \& Tajadod, 2006).

Quais as mudanças profundas no Irã atual? Como esse povo fascinante conseguirá transformar-se? Por enquanto, aproveitemos todas as pontes para aprofundar o conhecimento dessa atraente tradição da amada terra de Nahal, até agora mais difundida entre nós por meio do cinema.

\section{Nota}

1 Este artigo foi escrito antes das eleições no Irã em 2009.

\section{Referências}

TAJADOD, N. Rumi Le brûlé. Paris: JC Lattès, 2004.

MATTA, F.; TAJADOD, N. Sur les pas de Rumi. Pref. Jean-Claude Carrière. Paris: Albin Michel, 2006.

Betty Mindlin é doutora em antropologia e autora de Diários da floresta (Terceiro Nome, 2006), e de sete livros em coautoria com narradores indígenas.

@ - arampia@uol.com.br 